\title{
RELATIONSHIPS BETWEEN FRUGIVOROUS- BIRDS AND THEIR HABITATS IN FRAGMENTED FOREST AREAS NEAR TO VILLAVICENCIO CITY, VILLAVICENCIO, META, COLOMBIA.
}

\author{
Rodrigo Isaac Velosa Caicedo ${ }^{*}$, Adriana Alejandra Bernal Jiménez² \\ 1* Santo Tomás University, Villavicencio, Faculty of Environmental Engineering, Villavicencio, Meta, Colombia \\ rodrigovelosa@usantotomas.edu.co \\ ${ }^{2}$ Santo Tomás University, Villavicencio, Faculty of Environmental Engineering, Villavicencio, Meta, Colombia \\ adrianabernal@usantotomas.edu.co
}

Received for publication: 03/08/2019 - Accepted for publication: 29/10/2019

\begin{abstract}
Resumo
Relações entre aves frugívoras e seus habitats em áreas florestais fragmentadas próximas à cidade de Villavicencio, Villavicencio, Meta, Colômbia. A degradação dos ecossistemas do sopé das planícies é um dos maiores problemas ecológicos nas áreas vizinhas à cidade de Villavicencio, Meta. A geração de fragmentos produz novas condições para o estabelecimento de guildas de pássaros. Este estudo foi realizado durante o período de 2017-2018 em áreas do campus Loma Linda da Universidade Santo Tomás. Foi avaliado se as áreas interiores de floresta, fronteira e pastagem constituem habitats que suportam o estabelecimento de aves frugívoras. Fatores-chave que afetam a riqueza, diversidade e abundância de espécies dej aves foram identificados, a partir dos quais foram feitas recomendações para o estabelecimento de medidas de conservação. A riqueza de pássaros e sua abundância se correlacionaram positivamente com valores intermediários de riqueza e diversidade de plantas e com a presença e cobertura de espécies de palmeiras e lianas. A abundância e diversidade de espécies de aves frugívoras eram maiores nas áreas de fronteira e menores nas pastagens e florestas interiores. Parece que a diversidade do habitat nas áreas de fronteira de zonas fragmentadas aumenta a diversidade de aves frugívoras por meio de um aumento na abundância de aves. Recomenda-se o enriquecimento artificial com várias espécies de árvores - arbustos e palmeiras das bordas e áreas internas da floresta, e a manutenção de árvores e arbustos remanescentes em áreas de pastagem infestante.

Palavras-chave: fragmentação, aves frugívoras, diversidade, regeneração natural.
\end{abstract}

\begin{abstract}
The degradation of the Llanos foothill ecosystems is one of the biggest ecological problems in the areas surrounding the city of Villavicencio, Meta. The generation of fragments produces new conditions for the establishment of bird guilds. This study was carried out during 2017 - 2018 in areas of the campus Loma Linda at the Santo Tomas University. It was evaluated whether the forest interior, forest border and grassland areas constitute habitats that support the establishment of frugivorous birds. The key factors that affect the richness, diversity and abundance of bird species were identified, from which recommendations were made for the establishment of conservation measures. The richness of birds and their abundance was positively correlated with intermediate values of plant richness and diversity and with the presence and coverage of species of palms and lianas. The abundance and diversity of frugivorous birds were higher in border areas and lower in grasslands and forest interiors. Apparently the diversity of the habitat in border areas of fragmented lands increases the diversity of frugivorous birds through an increase in the abundance values. Artificial enrichment is recommended with different tree, shrubs and palms species planted in the edge and interior areas of the forest, and the maintenance of remaining trees and shrubs in the areas of shrub grasslands.

Keywords: fragmentation, frugivorous-birds, diversity, natural regeneration.
\end{abstract}

\section{INTRODUCTION}

Habitat quality models that relate the occurrence of bird assemblies with the characteristics of the occupied habitat have been frequently referenced in the literature (KENNEDY et al., 2011). Such models are influenced by the spatial scale that is used which includes not only the hierarchical structure or interdependence of the different environmental variables that are considered, but also the hierarchical responses or interdependence of the birds towards the habitat they are occupying (SMITH et al., 2011; KENNEDY et al., 2010). However, there are still information gaps related mainly to the predictive capacity of the models when trying to associate particular species of birds with particular types of occupied habitats at different spatial scales (KENNEDY et al., 2010).

Although different studies of bird-habitat relationships have used different hierarchical approaches using regional scales, landscape level or plot scale, with greater emphasis on the latter (LEVEAU, 2019; SHOFFNER $e t$ al., 2018; FREEMAN et al., 2015), there are few studies that have attempted to relate the influence of habitat distinctive types on the occurrence and characteristics of the habitat by species of frugivorous birds. In the eastern plains of Colombia and particularly in the vicinity of the city of Villavicencio, piedmont ecosystems are susceptible

FLORESTA, Curitiba, PR, v. 51, n. 1, p. 230-239, jan/mar 2021. 
to human disturbances such as deforestation, erosion and landslides, associated with an increase in urban pressure on these areas. Although there is no documented evidence of the effects of these activities on the structure and functioning of these ecosystems, it is assumed that such activities have an impact on resident bird populations, including frugivorous. Importantly, the remaining habitats can act as a refuge for a number of species of frugivorous birds. Environmental factors and the type of habitat or biotope occupied also play an important role in the conformation and persistence of bird assemblies (KRYNSKIA; GOLAWSKI, 2019; IMAI et al., 2017; FREEMAN et al., 2015; ESCRIBANO-AVILA et al.,2014).

Santo Tomas University at its Loma Linda campus has a forested relict of 8 ha in the process of natural regeneration that includes fragmented areas, grassland areas and a road that crosses part of the campus. However, no studies have been conducted on the composition and distribution of frugivorous bird species that may potentially favor the natural regeneration of the site, nor have the characteristics of the habitat occupied that may increase habitat availability for potentially useful species for restoration been identified. The succession of the vegetation depends to a large extent both on the seed rain dispersed by birds and from the buried seed bank in the ground (VELOSA, et al., 2018; VALOIS - CUESTA, et al., 2016). This study relates the variation in the composition and distribution of frugivorous bird species with the characteristics of the habitat occupied in three (3) piedmont biotopes (forest interior, forest edge and weed grassland). Habitat types play an important role in the formation and maintenance of bird guilds in modified environments (KRYNSKI; GOLAWSKI, 2019). Recommendations are also made for the management of such habitats that could be useful for the conservation of frugivorous birds in fragmented foothills.

\section{MATERIALS AND METHODS}

The study area is part of the green belt of the municipality of Villavicencio within the sub-humid forest biome and is located on the Loma Linda campus of Santo Tomas University, ( $4^{\circ} 06^{\prime} 38.83^{\prime}{ }^{\prime} \mathrm{N} ; 73^{\circ} 39^{\prime} 26.41^{\prime}$ ' $\left.\mathrm{O}\right)$, eastern slope of the eastern mountain range, at a height of $467 \mathrm{~m}$ above sea level, on the right bank of the road that leads from Villavicencio to the municipality of Acacias, Meta (Figure 1).

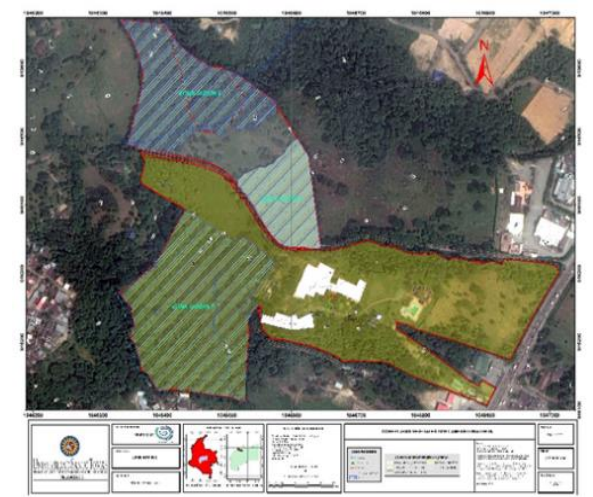

Figura 1. Mapa da capa do campus Loma Linda, Universidade Santo Tomas, Villavicencio, Meta, Colômbia . Figure 1. Cover map of Loma Linda campus, Santo Tomas University, Villavicencio, Meta, Colombia.

The selected study area includes two forest fragments of similar size (4.0 ha each), separated by a reel road, within which the following three (3) biotopes were differentiated:

a. Forest interior in regeneration. Characterized by sectors in different stages of ecological succession (mature forest, forest in intermediate stage of succession and forest in early stage of succession). In general, it corresponds to a high fragmented forest where Enterolobium schomburgkii Benth and Cecropia engleriana Snethl stand out as predominant species in a succession of 25-30 years.

b. Forest edge. It corresponds to an interphase zone of unknown amplitude between the interior of the dense forest and areas of open grassland.

c. Weed grassland. Coverage with presence of secondary vegetation; with isolated trees and predominance of grasses such as Andropogon bicornis (L.), Axonopus micay García-Barr and Cyperus luzulae (L.) Retz. Among the regenerating secondary vegetation, the following species stand out: Cecropia engleriana Snethl, Vismia macrophylla Kunth, Vochysia lehmannii Hieron, and Urera baccifera (L.) Gaudich ex Wedd.

The average annual rainfall is $4,383 \mathrm{~mm} /$ year. It has a dry season which runs from December to March and a rainy season from April to November. The average temperature is $25.5^{\circ} \mathrm{C}$ and the relative humidity during the year is between $67 \%$ and $83 \%$, being higher in the months of June and July and lower in the first quarter of the year (INSTITUTE OF HYDROLOGY, METEOROLOGY AND ENVIRONMENTAL STUDIES -IDEAM, 
2010); the soils are characterized by a light to moderately steep relief, with slopes $25-75 \%$, poor in nutrients, strong reaction to extremely acid, and moderately thick to thin textures.

\section{Establishment of sampling transects}

In each of the biotopes, except in the open areas of the campus, $50 \mathrm{~m} \times 2 \mathrm{~m}$ transects were established in line to determine the floristic composition and structure (vertical and horizontal) of the vegetation at the rate of: five (5) transects in the interior of the forest, two (2) transects at the edge of the forest and two (2) transects in the weed grassland. The transects were separated by a distance of $50-100 \mathrm{~m}$ between their central points to ensure independence in bird censuses.

\section{Bird censuses}

For the censuses of birds made from the center of each transect, the method of counting at fixed radius points was used. At the midpoint of each transect, a period of 10 minutes was used, registering the species and the distance from the detection point to the center of the transect. The birds detected were recorded within a radius of no more than $50 \mathrm{~m}$ from the observation point of each transect and those that escaped as the observer approached the transect. Each fixed observation point was censored 15 times during a study period of 7 months in two different observation periods, namely: from 6:30 a.m. to 9:00 a.m., and from 3:00 p.m. to 5:30 p.m. Frugivorous birds detected outside the transect zone were also recorded, but not included in the habitat utilization analysis.

\section{Habitat variables}

Vegetation structure: The floristic structure and composition was determined based on all individuals with CAP> $4.0 \mathrm{~cm}$. For each individual registered within the plot, the following information was established: Circumference at breast height - CAP (cm), Total height (m), Shaft height (m), Larger Diameter -Dm (m) and Minor Diameter -Dn (m) of the crown. Likewise, the coordinates of the start and end point of the transect were recorded, together with the height s.n.m. of each point. In each transect the number of species, the coverage by plant species in percentage (discriminated for tree, shrub, herbaceous, palms and liana species) and the presence of plant species in percentage (discriminated for tree, shrub, herbaceous, palms and liana species) were recorded. The midpoint of each coverage class and presence defined was averaged in order to obtain values of the two variables for each transect.

Floristic composition and diversity: No specimens were collected and their taxonomic determination was carried out by the dendrologist Francisco Castro. As an expression of alpha diversity, Fisher's alpha diversity index was calculated using the Past vers program. 3.0. As an expression of the homogeneity of the floristic composition between transects, the Bray-Curtis index was used to generate the similarity matrix and the classification dendrogram was developed.

\section{Statistical analysis}

An analysis of variance (ANOVA) was carried out to test the null hypothesis that there are no differences in the composition/abundance of the avian community among the biotopes considered. The Tukey multiple comparison test $(p=0.05)$ was used to establish the differences between the biotopes. Starting from the matrix of similarity generated, a dendrogram was constructed to group the bird species by means of the technique of average grouping into groups. The multivariate technique called "factor analysis" (F.A.) was used with a solution of main components to group bird species according to their relative position within the habitat of the study area. To obtain the coordinates corresponding to each of the observations (species), a regression analysis of the factors generated from the analysis of factors on each of the bird species was performed. The resulting regression coefficients were used as an ordination axes, taking two factors at the same time to graphically represent the position of each species within the study habitat.

Although the Factors Analysis provides information on the bird-habitat relationships of individual species, its main objective is to determine the relative effects of the habitat on the community or bird guild included as a whole. For this reason, Generalized Linear Models (GLM) were used to determine the key habitat conditions that determine the variations in composition and diversity of frugivorous bird species among the biotopes considered. A separate GLM was used for each of the dependent variables included: bird abundance, bird richness and bird diversity according to Shannon index. According to the distribution of the dependent variables, the generalized linear model with the Poisson distribution function was used for both the abundance, richness and diversity of birds according to Shannon index. The independent variables included in the models were the values of Factors 1, 2 and 3 derived from the Factors Analysis, and the following habitat variables: Presence (in percentage) of tree, shrub, herbaceous, liana and palms species; average coverage (in square meters) of tree, shrub, herbaceous, liana and palms species; number of species and plant diversity index (Fisher's alpha). Only results with a probability $\alpha \leq 0.002$ were considered statistically significant. Statistical analyses were performed with Past version 3.2. 


\section{RESULTS}

The censuses of frugivorous birds included 2,103 individuals belonging to 30 species. Of the total, 1,128 individuals (53.6\%) were located in forest edge, 861 (40.9\%) in grassland areas and only 114 (5.4\%) individuals in forest interior areas (Table 1).

Table 1. Abundance distributions of 30 frugivorous bird species, Loma Linda Campus.

Tabela 1. Distribuições de abundância de 30 espécies de aves frugívoras, Loma Linda Campus.

\begin{tabular}{|c|c|c|c|c|c|c|}
\hline \multirow{2}{*}{ No. } & \multirow{2}{*}{ SPECIE } & \multirow{2}{*}{ ORDER } & \multirow{2}{*}{ FAMILY } & \multicolumn{3}{|c|}{ ABUNDANCE } \\
\hline & & & & $\begin{array}{c}\text { FOREST } \\
\text { INTERIOR }\end{array}$ & $\begin{array}{l}\text { FOREST } \\
\text { EDGE }\end{array}$ & GRASSLAND \\
\hline 1 & $\begin{array}{l}\text { Ortalis guttata, Spix } \\
1825\end{array}$ & Galliformes & Cracidae & 35 & 61 & 0 \\
\hline 2 & $\begin{array}{l}\text { Zenaida auriculata, } \\
\text { Des Murs } 1847\end{array}$ & Columbiformes & Columbidae & 5 & 33 & 26 \\
\hline 3 & $\begin{array}{l}\text { Columba } \\
\text { cayannensis, } \\
\text { Bonnaterre } 1792\end{array}$ & Columbiformes & Columbidae & 0 & 44 & 9 \\
\hline 4 & $\begin{array}{l}\text { Leptotila rufaxilla, } \\
\text { Richard and Bernard } \\
1792\end{array}$ & Columbiformes & Columbidae & 0 & 26 & 3 \\
\hline 5 & $\begin{array}{l}\text { Eupsittula pertinax, } \\
\text { Linnaeus } 1758\end{array}$ & Psittaciformes & Psittacidae & 0 & 8 & 2 \\
\hline 6 & $\begin{array}{l}\text { Brotogeris jugularis, } \\
\text { Muller } 1776\end{array}$ & Psittaciformes & Psittacidae & 0 & 2 & 7 \\
\hline 7 & $\begin{array}{l}\text { Piaya cayana, } \\
\text { Linnaeus } 1776\end{array}$ & Cuculiformes & Cuculidae & 2 & 35 & 24 \\
\hline 8 & $\begin{array}{l}\text { Trogon viridis, } \\
\text { Linnaeus } 1766\end{array}$ & Trogoniformes & Trogonidae & 1 & 9 & 0 \\
\hline 9 & $\begin{array}{l}\text { Pteroglossus } \\
\text { castanotis, Gould, } \\
1836\end{array}$ & Piciformes & Ramphastidae & 5 & 15 & 11 \\
\hline 10 & $\begin{array}{l}\text { Pteroglossus } \\
\text { inscriptus, } \\
\text { Swainson, } 1822\end{array}$ & Piciformes & Ramphastidae & 2 & 9 & 3 \\
\hline 11 & $\begin{array}{l}\text { Myiozetetes } \\
\text { cayanensis, } \\
\text { Linnaeus } 1766\end{array}$ & Passeriformes & Tyrannidae & 0 & 94 & 58 \\
\hline 12 & $\begin{array}{l}\text { Pitangus } \\
\text { sulphuratus, } \\
\text { Linnaeus } 1766\end{array}$ & Passeriformes & Tyrannidae & 0 & 54 & 78 \\
\hline 13 & $\begin{array}{l}\text { Megarynchus } \\
\text { pitangua, Linnaeus } \\
1766\end{array}$ & Passeriformes & Tyrannidae & 0 & 17 & 25 \\
\hline 14 & $\begin{array}{l}\text { Tyrannus } \\
\text { melancholicus, } \\
\text { Vieillot } 1819\end{array}$ & Passeriformes & Tyrannidae & 0 & 65 & 94 \\
\hline 15 & $\begin{array}{l}\text { Momotus momota, } \\
\text { Linnaeus } 1766\end{array}$ & Coraciiformes & Momotidae & 1 & 8 & 0 \\
\hline 16 & $\begin{array}{l}\text { Manacus manacus, } \\
\text { Linnaeus } 1766\end{array}$ & Passeriformes & Pipridae & 5 & 59 & 17 \\
\hline 17 & $\begin{array}{l}\text { Cyanocorax } \\
\text { violaceus, Du Bus } \\
\text { de Gisignies } 1847\end{array}$ & Passeriformes & Corvidae & 21 & 76 & 35 \\
\hline
\end{tabular}

FLORESTA, Curitiba, PR, v. 51, n. 1, p. 230-239, jan/mar 2021. 


\begin{tabular}{|c|c|c|c|c|c|c|}
\hline 18 & $\begin{array}{l}\text { Catharus minimus, } \\
\text { Lafresnaye } 1848\end{array}$ & Passeriformes & Turdidae & 2 & 27 & 0 \\
\hline 19 & $\begin{array}{l}\text { Catharus nudigenis, } \\
\text { Lafresnaye } 1848\end{array}$ & Passeriformes & Turdidae & 0 & 45 & 37 \\
\hline 20 & $\begin{array}{l}\text { Turdus ignobilis, } \\
\text { Sclater, } \mathrm{Pl}, 1858\end{array}$ & Passeriformes & Turdidae & 0 & 52 & 47 \\
\hline 21 & $\begin{array}{l}\text { Turdus albicollis, } \\
\text { Vieillot, } 1818\end{array}$ & Passeriformes & Turdidae & 3 & 15 & 7 \\
\hline 22 & $\begin{array}{l}\text { Turdus leucomelas, } \\
\text { Vieillot } 1818\end{array}$ & Passeriformes & Turdidae & 0 & 38 & 29 \\
\hline 23 & $\begin{array}{l}\text { Mimus gilvus, } \\
\text { Vieillot } 1808\end{array}$ & Passeriformes & Mimidae & 0 & 27 & 49 \\
\hline 24 & $\begin{array}{l}\text { Ramphocelus carbo, } \\
\text { Pallas, } 1764\end{array}$ & Passeriformes & Thraupidae & 5 & 81 & 75 \\
\hline 25 & $\begin{array}{l}\text { Thraupis episcopus, } \\
\text { Linnaeus } 1766\end{array}$ & Passeriformes & Thraupidae & 12 & 92 & 69 \\
\hline 26 & $\begin{array}{l}\text { Thraupis palmarum, } \\
\text { Wied, } 1821\end{array}$ & Passeriformes & Thraupidae & 15 & 77 & 85 \\
\hline 27 & $\begin{array}{l}\text { Tangara cayana, } \\
\text { Linnaeus } 1766\end{array}$ & Passeriformes & Thraupidae & 0 & 15 & 9 \\
\hline 28 & $\begin{array}{l}\text { Psarocolius } \\
\text { angustifrons, Spix, } \\
1824\end{array}$ & Passeriformes & Icteridae & 0 & 2 & 11 \\
\hline 29 & $\begin{array}{l}\text { Psarocolius } \\
\text { decumanus, Pallas, } \\
1769\end{array}$ & Passeriformes & Icteridae & 0 & 7 & 25 \\
\hline 30 & $\begin{array}{l}\text { Euphonia } \\
\text { laniirostris, } \\
\text { d'Orbigny \& } \\
\text { Lafresnaye, } 1837\end{array}$ & Passeriformes & Fringillidae & 0 & 35 & 26 \\
\hline
\end{tabular}

ANOVA rejected the null hypothesis that there are no differences in the frugivorous avian community between the habitat types considered $\left(\mathrm{kw}=37.74, \mathrm{df}=2, \mathrm{p}=5.1 \times 10^{-9}\right)$. The results of the multiple comparison test indicate that only the forest and grassland edge habitats were not significantly different $(\mathrm{kw}=2,364, \mathrm{df}=2, \mathrm{p}$ $=0.1239$ ) with respect to the composition of the frugivorous avian community. The rest of the comparisons between habitat types showed significant differences in the composition of the avian community $\left(\mathrm{p} \leq 5.3 \times 10^{-6}\right)$.

Habitat overlap dendrograms are useful for visualizing relationships within the bird community. In the elaborated dendrogram, three groupings were defined (Figure 2). One of them, made up of the species Trogon viridis (L.), Ortalis guttata Spix, Catharus minimus Frederic de Lafresnaye and Momotus momota (L.) was characterized by the absence of records of these species in the grassland biotope. The second grouping consisting of the largest number of frugivorous species was characterized by its high abundance in the forest edge biotope. Among these species, the following stand out: Zenaida auriculata Des Murs, Piaya cayana (L.), Cyanocorax violaceus Du Bus de Gisignies, Manacus manacus (L.), Catharus nudigenis Lafresnaye, Turdus ignobilis Sclater, Turdus leucomelas Vieillot, Euphonia laniirostris d’Orbigny \& Lafresnaye, Myiozetetes cayannensis (L.), Ramphocelus carbo, Pallas and Thraupis episcopus (L.) The third of the groups consisting of nine (9) species was defined by their low abundance and/or absence of records inside the forest. This group was made up of the following species: Columba cayannensis Bonnaterre, Leptotila rufaxilla Richard and Bernard, Pteroglossus castanotis Gould, Turdus albicollis Vieillot, Tangara cayana (L.), Eupsittula pertinax (L.), Pteroglossus inscriptus Swainson, Brotogeris jugularis Muller, and Psarocolius angustifrons Spix. 


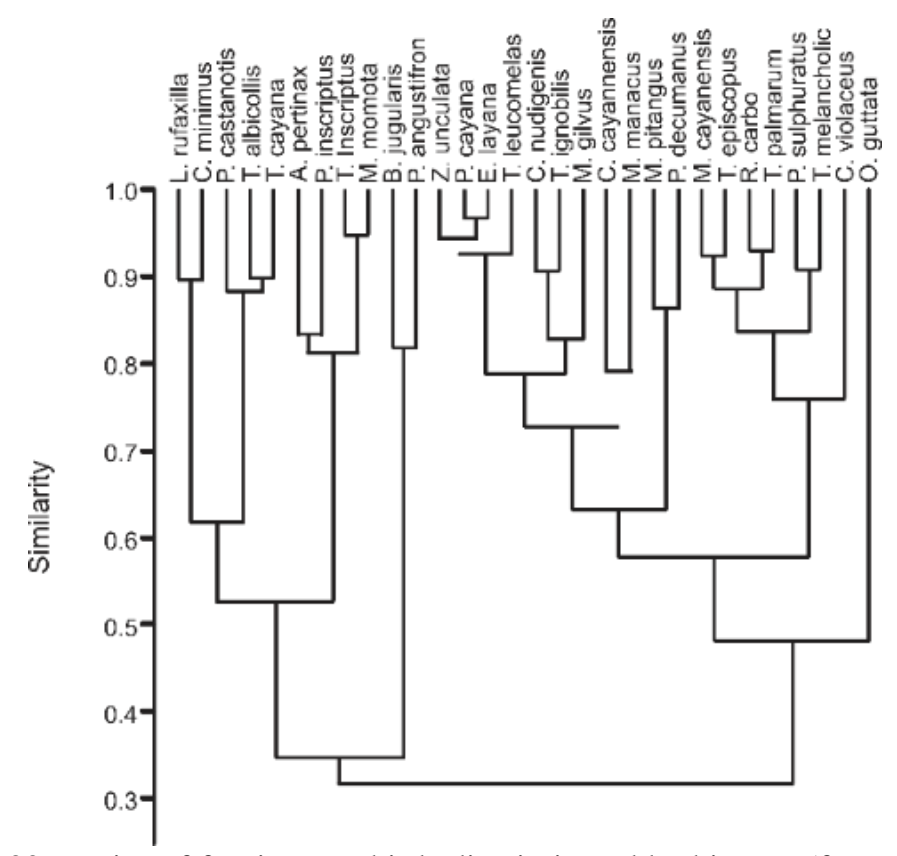

Figure 2. Habitat overlap of 30 species of frugivorous birds discriminated by biotope (forest interior, forest edge and grassland) using the Bray-Curtis similarity index.

Figura 2. Sobreposição de habitat de 30 espécies de aves frugívoras discriminadas por biótopo (interior da floresta, borda da floresta e pastagem) usando o índice de similaridade de Bray-Curtis.

The factor analysis performed produced 3 factors which explained $100 \%$ of the original variance. Factor 1 was interpreted as a tree-shrub gradient which was related to the abundance of tree-shrub species, the cover of tree species, the richness of plant species and the Fisher's alpha diversity index.

Factor 2 was interpreted as an herbaceous gradient resulting from the combination of the abundance and coverage of herbaceous species and the abundance of palm species. Factor 3 represented a gradient of abundance and coverage of liana species associated with the coverage of palm species.

The graphs of the regression coefficients of the species of frugivorous birds taken two factors at the same time illustrate the "location" of the species within the studied habitat. Figure 3 illustrates the position of the centroids of bird species in relation to the tree-shrub gradient (Factor 1) and the herbaceous gradient (Factor 2).

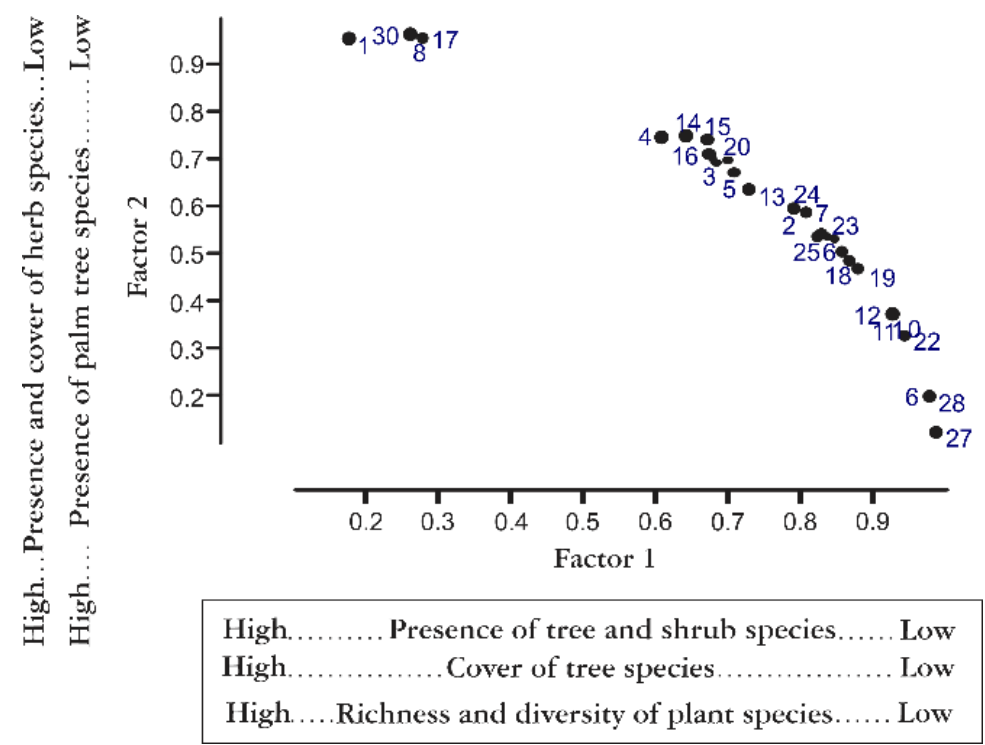

Figure 3. Centroids of frugivorous bird species on Factors 1 and 2.

Figura 3. Centróides de espécies de aves frugívoras nos Fatores 1 e 2.

Forest edge areas, followed by successional intermediate areas inside the forest, recorded the greatest abundance and coverage of tree species, but with low values in herbaceous species. However, forest borders 
recorded the lowest values of presence and coverage of palm species. The highest values of richness and diversity of species were recorded in the mature forest areas within the forest. Weed grassland areas had the lowest values of presence and coverage of tree - shrub species, and richness and diversity, but they were the areas with the greatest coverage of herbaceous species and a high number of seedlings of palm species.

The richness and diversity of plants (Fisher's alpha) had a significant effect on the number (GLM; G = $9,456, p=0.002$ and $\mathrm{G}=10,938, \mathrm{p} \leq 0.001$ respectively) and abundance of frugivorous bird species (GLM; $\mathrm{G}=$ $40.46, p \leq 0.001$ and $\mathrm{G}=44.74, \mathrm{p} \leq 0.001$ respectively). The richness, abundance and diversity of frugivorous bird species was lower in forest interior areas compared to those with forest edge and weed grassland (Figure 4). The richness and abundance of birds was also dependent on the coverage - and presence of palm species (GLM; G = $10.12, p \leq 0.001$ and $G=55.1, p \leq 0.001$ respectively $)$ and the coverage - and presence of liana species $(G=-$ $10.39, p=0.008$ and $\mathrm{G}=33.29, \mathrm{p} \leq 0.001)$. Above all, the abundance and diversity of frugivorous bird species was higher in forest edge areas and lower in weed grasslands.

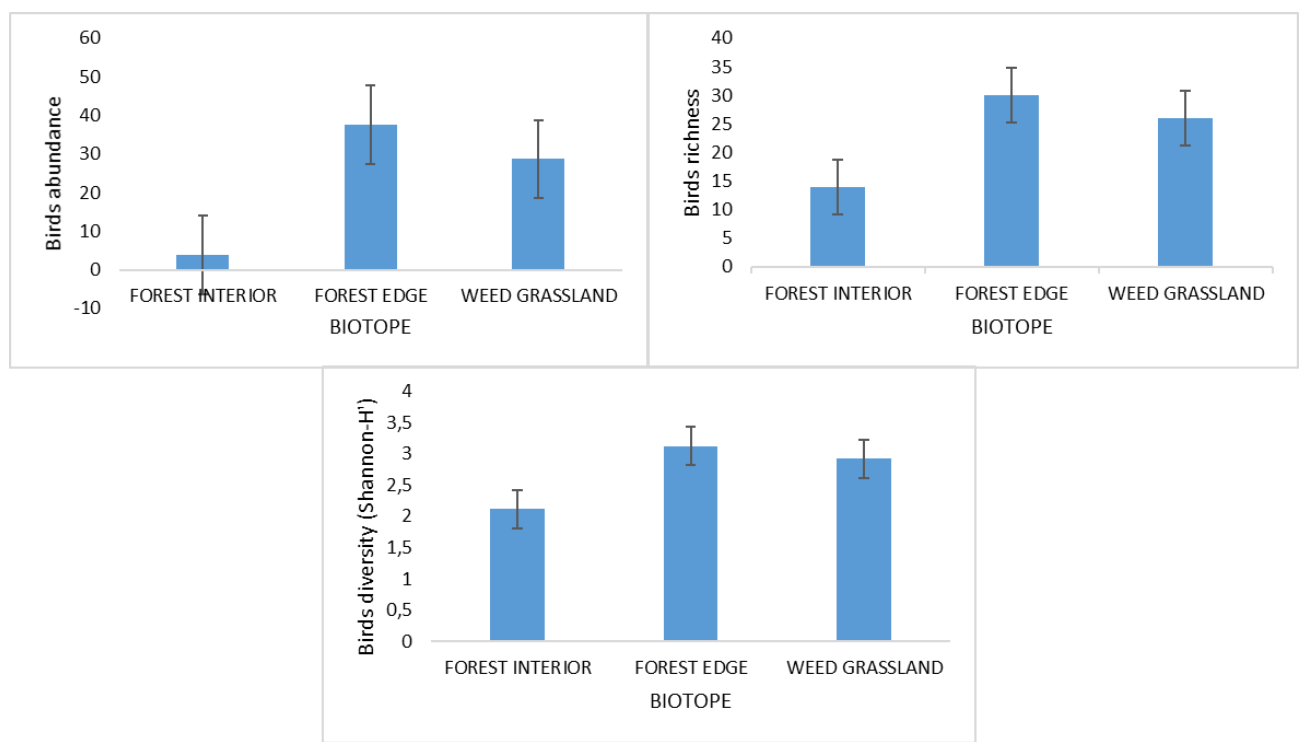

Figure 4. Comparison of the average abundance, richness and diversity of frugivorous birds discriminated by type of biotope showing the standard error, Loma Linda Campus, Santo Tomás University.

Figura 4. Comparação da abundância, riqueza e diversidade médias de aves frugívoras discriminadas por tipo de biótopo apresentando o erro padrão, Campus Loma Linda, Universidade de Santo Tomás.

Although not significantly, the type of vegetation covers most related to the abundance of bird species was recorded inside the forest (MANOVA, F $1.43=3.516, \mathrm{p}=0.06$ ) (Figure 5). The diversity of frugivorous birds (Shannon $\mathrm{H}^{\prime}$ ) was not significantly related to any of the measured habitat variables. Habitat variables grouped in Factors 1, 2 and 3 of the Factors Analysis did not significantly affect the richness, abundance and diversity (Shannon $\mathrm{H}^{\prime}$ ) of frugivorous birds (Table 3).

Table 3. Results of the Generalized Linear Model - GLM - on the influence of habitat factors on the richness, abundance and diversity of bird species (Shannon) in fragmented areas of llanos piedmont near to Villavicencio, Meta. (ES = Standard error; $p=$ Level of significance).

Tabela 3. Resultados do Modelo Linear Generalizado - GLM - sobre a influência de fatores de habitat na riqueza, abundância e diversidade de espécies de aves (Shannon) em áreas fragmentadas de llanos piemonte próximo a Villavicencio, Meta. (ES = erro padrão; $\mathrm{p}=$ nível de significância).

\begin{tabular}{llll}
\hline \multicolumn{1}{c}{ Variables } & \multicolumn{1}{c}{ Estimator } & \multicolumn{1}{c}{ ES } & \multicolumn{1}{c}{ p } \\
\hline Diversity of Birds & & & \\
Presence of forest arboreal species(\%) & 0.0004 & 0.0025 & 0.863 \\
Presence of shrub species(\%) & -0.0054 & 0.0218 & 0.803 \\
Presence of herbaceous species(\%) & 0.0019 & 0.003 & 0.53 \\
Presence of liana species (\%) & -0.7321 & 0.2151 & 0.002 \\
Presence of palm species (\%) & -1.5606 & 0.4379 & 0.002 \\
Coverage (average) of tree species (m2) & 0.0129 & 0.0085 & 0.144
\end{tabular}




\begin{tabular}{|c|c|c|c|}
\hline Coverage (average) of shrub species (m2) & -0.039 & 0.0496 & 0.426 \\
\hline Coverage (average) of herbaceous species (m2) & 0.0083 & 0.0079 & 0.301 \\
\hline Coverage (average) of liana species (m2) & -0.0555 & 0.0217 & 0.008 \\
\hline Coverage (average) of palm species (m2) & -0.0482 & 0.0164 & 0.001 \\
\hline Richness of plants & -0.5928 & 0.1883 & 0.002 \\
\hline Fisher's alpha diversity index & 0.0282 & 0.0088 & 0.0009 \\
\hline Factor 1 & -8.3497 & 6.0255 & 0.1959 \\
\hline Factor 2 & -1.0638 & 5.9632 & 0.8619 \\
\hline Factor 3 & -5.4387 & 6.3996 & 0.4152 \\
\hline \multicolumn{4}{|l|}{ Abundance of Birds } \\
\hline Presence of tree species $(\%)$ & 0.002 & 0.0025 & 0.4177 \\
\hline Presence of shrub species (\%) & 0.0094 & 0.0213 & 0.6565 \\
\hline Presence of herbaceous species $(\%)$ & 0.0021 & 0.0029 & 0.464 \\
\hline Presence of liana species (\%) & -1.6447 & 0.1713 & $2.28 \mathrm{E}-12$ \\
\hline Presence of palm species (\%) & -0.1839 & 0.0355 & $1.40 \mathrm{E}-09$ \\
\hline Coverage (average) of tree species (m2) & 0.5945 & 0.247 & 0.006 \\
\hline Coverage (average) of shrub species (m2) & -0.0872 & 0.0504 & 0.075 \\
\hline Coverage (average) of herbaceous species (m2) & 0.0094 & 0.0076 & 0.2285 \\
\hline Coverage (average) of liana species (m2) & -0.1298 & 0.0249 & 7.91E-09 \\
\hline Coverage (average) of palm species (m2) & -0.1541 & 0.0292 & $1.15 \mathrm{E}-13$ \\
\hline Richness of plants & -0.0616 & 0.01 & $2.00 \mathrm{E}-10$ \\
\hline Fisher's alpha diversity index & -0.06 & 0.0098 & $2.25 \mathrm{E}-11$ \\
\hline Factor 1 & -15.26 & 11.294 & $2.06 \mathrm{E}-01$ \\
\hline Factor 2 & -0.9242 & 11.147 & $9.35 \mathrm{E}-01$ \\
\hline Factor 3 & -11.37 & 11.837 & $3.59 \mathrm{E}-01$ \\
\hline \multicolumn{4}{|l|}{ Diversity (Shannon $H^{\prime}$ ) } \\
\hline Presence of tree species $(\%)$ & 0.00048 & 0.007 & $9.44 \mathrm{E}-01$ \\
\hline Presence of shrub species (\%) & 0.0068 & 0.06 & $9.10 \mathrm{E}-01$ \\
\hline Presence of herbaceous species (\%) & 0.00016 & 0.0086 & $9.85 \mathrm{E}-01$ \\
\hline Presence of liana species $(\%)$ & -0.125 & 0.033 & $6.92 \mathrm{E}-01$ \\
\hline Presence of palm species (\%) & -0.0231 & 0.07 & 7.38E-01 \\
\hline Coverage (average) of tree species (m2) & 0.0039 & 0.0254 & 8.77E-01 \\
\hline Coverage (average) of shrub species (m2) & -0.0222 & 0.1345 & 8.67E-01 \\
\hline Coverage (average) of herbaceous species (m2) & 0.0017 & 0.0231 & $9.40 \mathrm{E}-01$ \\
\hline Coverage (average) of liana species (m2) & -0.0188 & 0.0562 & 7.35E-01 \\
\hline Coverage (average) of palm species (m2) & -0.017 & 0.0389 & $8.52 \mathrm{E}-01$ \\
\hline Richness of Plants & -0.0095 & 0.0264 & 7.17E-01 \\
\hline Fisher's alpha diversity index & -0.0063 & 0.0226 & $7.78 \mathrm{E}-01$ \\
\hline Factor 1 & -0.426 & 0.198 & $5.70 \mathrm{E}-02$ \\
\hline Factor 2 & -0.198 & 0.208 & 3.62E-01 \\
\hline Factor 3 & -0.149 & 0.236 & $5.43 \mathrm{E}-01$ \\
\hline
\end{tabular}

\section{DISCUSSION}

Although only a small number of habitat types were included, the results of ANOVA and the multiple comparison test show significant differences in two (2) of the three (3) comparisons made with respect to the composition of frugivorous bird species. In the study area, vegetation types were considered distributed along different gradients with respect to the habitat of frugivorous birds. In one gradient, a type of vegetation is dominated by the presence and coverage of tree-shrub species and by the richness and diversity of plants (Factor 
1) and in the other, by the presence and coverage of herbaceous species and by the presence of palm species (Factor 2 ). An additional gradient (factor 3) was associated with the abundance and coverage of liana species and the coverage of palm species.

The reported evidence regarding variations in the composition of frugivorous bird species indicates that significant differences can be found between specific units of differentiated local vegetation such as biotopes, which represent portions of important habitats for birds. In this study and in an area of 8 ha. a total of 30 species of frugivorous birds corresponding to $30 \%$ of the total bird species reported for the area were recorded. It is remarkable the occurrence of 11 species of birds of granivorous-frugivorous habits, including the following with low abundance in the study area: Trogon viridis, Brotogeris jugularis, , Pteroglossus inscriptus and Psarocolius angustifrons. Abundance of species such as Ortalis guttata, Columba cayannensis, Manacus manacus, and Cyanocorax violaceus were higher in edge forest areas in comparison with those of adjacent weed grasslands. This suggests that forest edges may be important for the conservation of frugivorous birds in fragmented areas of piedmont since they can be occupied by multiple species, including some with low population abundance.

The definition of habitat factors that explain the total variability in the occurrence of frugivorous birds in fragmented areas is difficult. Although in this study the variability explained by the first two factors of the Factor Analysis was $89.3 \%$, not all the variables that could have a significant effect on the variability of the composition of frugivorous birds were included. Factors such as the analysis of food habits of the reported species and the distribution and abundance of fruits were not included. However, the dynamics of changes in plant cover due to the fragmentation effect in the study area and the definition of three (3) specific groupings of bird species associated with such changes suggest a composition of frugivorous birds without much rotation, which would lead to the establishment of relatively stable bird guilds.

The factors that significantly determine the variability of the species according to the type of biotope they occupy, may reflect the bird's preferences for specific habitat types. In this study, the occurrence of Ortalis guttata, Trogon viridis, and Catharus minimus was positively correlated with high values of both richness and diversity of plant species, tree and shrubs cover and palms species. These species recorded the highest abundance values in forest edge areas compared to areas of weedy grassland and forest interior, which reflects the preference of these birds for forest edge. In contrast, the presence of species such as Brotogeris jugularis, Psarocolius angustifrons and Psarocolius decumanus was positively correlated with low values of richness and diversity of plant species and high values of coverage of herbaceous species.

The role played by habitat diversity in determining the richness of bird species in fragmented and urban or semi-urban areas has been emphasized by different authors (PAKER, et al., 2014). In addition to this factor, the coverage of tree - shrub species and palms, apparently plays an important role in maintaining high levels of richness of frugivorous bird species in fragmented areas of foothills llanos. In the study area, despite its small size, seven (7) species of palms (Arecaceae) were registered that provide food for the birds of the site.

Discriminated by biotope, the richness and abundance of frugivorous bird species was greater in forestedge areas compared to areas of weedy grassland and forest interior. Presumably, habitat diversity in forest-edge areas of fragmented areas of llanos piedmont increases the diversity of frugivorous birds through an increase in bird abundance. Given the differences in the composition of the guild of frugivorous birds between biotopes, it could be inferred that their distribution is at the same level at which the bird species discriminate. However, this statement requires for its verification of studies on the differential preponderance of the species of frugivorous birds in a greater number of biotopes.

\section{CONCLUSIONS}

- The forest edge areas constitute an important refuge for different species of frugivorous birds.

- The type of habitat occupied affected the richness and abundance of frugivorous bird species.

- The maintenance of remaining trees and shrubs in the weedy grassland areas as catalytic nuclei of the succession process, the artificial enrichment with various tree - shrub and palm species of the edge and interior areas of the forest, can contribute to the retention and maintenance of valuable habitats for frugivorous birds.

\section{REFERENCES}

ESCRIBANO - AVILA, G.; CALVINO - CANCELA, M.; PIAS, B.; VIRGOS, E.; VALLADARES, F.; ESCUDERO, A. Diverse guilds provide complementary dispersal services in a woodland expansion process after land abandonment. Journal of Applied Ecology, Madrid, v. 51, p. 1701-1711, 2014. 
FREEMAN, A.N.D.; CATTERALL C.P.; FREEBODY, K. Use of restored habitat by rainforest birds is limited by spatial context and species' functional traits but not by their predicted climate sensitivity. Biological Conservation, Nathan, v. 186, p. 107-114, 2015.

IMAI, H.; NAKASHIZUKA, T.; OGURO, M. Environmental factors affecting the composition and diversity of the avian community in igune, a traditional agricultural landscape in northern Japan. Journal of Ecology and Environment, Tohoku, v. 41, p. 8, 2017.

INSTITUTO DE HIDROLOGIA, METEOROLOGIA Y ESTUDIOS AMBIENTALES -IDEAM. Leyenda Nacional de Coberturas de la Tierra - Metodología Corine Land Cover adaptada para Colombia Escala 1:100.000. Disponible en: http://www.ideam.gov.co/web/ecosistemas/metodologia-corine-land-cover. Acceso: 29/07/2018.

KENNEDY, C.M.; MARRA, P.P.; FAGAN, W.F.; NEEL, M.C. Landscape matrix and species traits mediate responses of Neotropical resident birds to forest fragmentation in Jamaica. Ecological Monographs, Maryland, v. 80, n. 4, p. 651-669, 2010.

KENNEDY, C.M.; CAMPBELL, E.H.; NEEL, M.C.; FAGAN, W.F.; MARRA, P.P. Landscape matrix mediates occupancy dynamics of Neotropical avian insectivores. Ecological Applications, Maryland, v. 21, n. 5, p. 18371850, 2011.

KRYNSKI, K.; GOLAWSKI, A. Effects of habitat type and intensity of use on the breeding birds of gravel pits in Poland. Ecological Engineering, Siedlce, v. 130, p. 110-116, 2019.

LEVEAU, L.M. Primary productivity and habitat diversity predict bird species richness and composition along urban - rural gradients of central Argentina, Urban Forestry \& Urban Greening, Buenos Aires, v. 43, p. 11, 2019.

PAKER, Y.; YOM - TOV, Y.; ALON - MOZES, T.; BARNEA, A. The effect of plant richness and urban garden structure on bird species richness, diversity and community structure. Landscape and Urban Planning, Tel-Aviv, v. 122 , p. $186-195,2014$.

SHOFFNER, A.; WILSON, A.M.; TANG, W.; GAGNE, S.A. The relative effects of forest amount, forest configuration, and urban matrix quality on forest breeding birds. Scientific Reports, East Lansing, 10.1038/s41598-018-35276-9, 2018.

SMITH, A.C.; FAHRIG, L.; FRANCIS, C.M. Landscape size affects the relative importance of habitat amount, habitat fragmentation, and matrix quality on forest birds. Ecography, Ottawa, v. 34, p. 103-113, 2011.

VALOIS - CUESTA, H.; MARTINEZ - RUIZ, C.; URRUTIA - RIVAS, Y. Formación del banco de semillas durante la revegetación temprana de áreas afectadas por la minería en un bosque pluvial tropical del Chocó, Colombia. Revista de Biología Tropical, Quibdó, v. 65, n. 1, p. 393 - 404, 2017.

VELOSA, R.I.; DOMINGUEZ, K.J.; ROMERO, Y. Composición y diversidad del banco de semillas en áreas urbanas fragmentadas de piedemonte, Villavicencio, Colombia. Ingenierías USBMed, Villavicencio, v. 9, n. 1, p. $86-96,2018$. 